ISSN $1978-3000$

\title{
Metabolic Responses on Transport Stress and the Effect on Meat Characteristics (A Review)
}

\author{
Suharyanto \\ Jurusan Peternakan Fakultas Pertanian Universitas Bengkulu \\ Jalan Raya Kandang Limun, Bengkulu. Telp. (0736) 2170 pst.219. \\ Suharyanto_wp@yahoo.com
}

\begin{abstract}
Transportation plays important role in animals and animal products business by distributing them from producers to consumers or from farm to slaughter house. Unfortunately, the transport from farm to slaughter house is a risky point for meat properties caused by transport stress. Glycogen and glucose metabolism in stressed animal is more fastened by epinephrine and norepinephrine. Glycogenolysis and glycolysis process can be in aerobic (TCA cycle) and anaerobic condition. If anaerobic condition is dominant, it will produce lactic acid increasingly and cause PSE meat. If the animals are able to maintain the physiological equilibrium by using muscle glycogen up, it causes glycogen deficiency and yields DFD meat. Both are considered as poor quality. Consequently, the products made from these kinds of meat have low properties and acceptability For avoiding both cases, pre-slaughter handling is an important stage. The ways of it are adequate resting time, giving electrolyte and sugar solution and so on.
\end{abstract}

Key words: metabolic, transport, stress, meat characteristics

\begin{abstract}
ABSTRAK
Transportasi memainkan peran penting dalam usaha peternakan dan hasil-hasil ternak dengan mendistribusikannya fari produsen ke konsumen. Akan tetapi, transportasi dari peternakan ke tempat pemotongan hewan merupakan titik riskan yang berpengaruh terhadap sifat-sifat daging yang disebabkan oleh stres transportasi. Glikogen dan glukosa pada ternak stres lebih dipacu oleh epineprin dan norepineprin. Proses glikogenolisis dan glikolisis dapat terjadi secara aerobik atau anaerobik. Jika proses anaerobik lebih dominan maka produksi asam laktat sangat tinggi dan menghasilkan daging PSE. Jika ternak mampu mempertahakan status fisiologi dalam kesetimbangan dengan menghabiskan glikogen otot dan ini menyebabkan daging DFD. Baik PSE maupun DFD merupakan daging yang berkualitas rendah, konskuensinya, produk olahan yang berasal dari keduanya juga memiliki sifat dan daya terima yang rendah. Untuk menghindari kasus-kasus tersebut maka perlu penanganan sebelum penyembelihan, yaitu dengan cara pengistirahatan yang cukup, pemberian elektrolit dan larutan gula dan lain-lain.
\end{abstract}

Key words: metabolik, transportasi, stres, karakteristik daging

\section{INTRODUCTION}

One of the factors affecting meat quality is post-harvest handling including transportation from farm to slaughter house. Animals are often stressed by transport and environmental factors such as temperature and humidity. The neglecting of these factors loses farmers economically, and obviously, decreases the quality of meat. The loss happening during transport and miss handling is highly in great quantities so that it needs a method to reduce the loss caused by transport and post-harvest handling (Grandin, 2000). 
The transport from farm to slaughter house is a risky point for meat properties. In addition, transportation system is also an important factor in the animals and animal products business chain from producers to consumers. Since animals can't move freely and are in standing position during transportation, these lead animals more stressful (Dewi, 2004). Furthermore, the transportation structure and infrastructure such as road and transportation facilities in Indonesia are inadequate; therefore, animals suffer from severe fatigued. personnel handling them. The impacts of stress on animal may cause both DFD (Dry, Firm, Dark) and PSE (Pale, Soft, Exudative) meat. DFD meat is characterized by meat with dark color, dry surface and firm texture, whereas PSE meat is indicated by pale color, soft texture and watery condition of meat. Both are considered as poor quality. Consequently, the products made from these kinds of meat have low properties and acceptability. Therefore, it is necessary to discuss the relationship between physiological responses caused

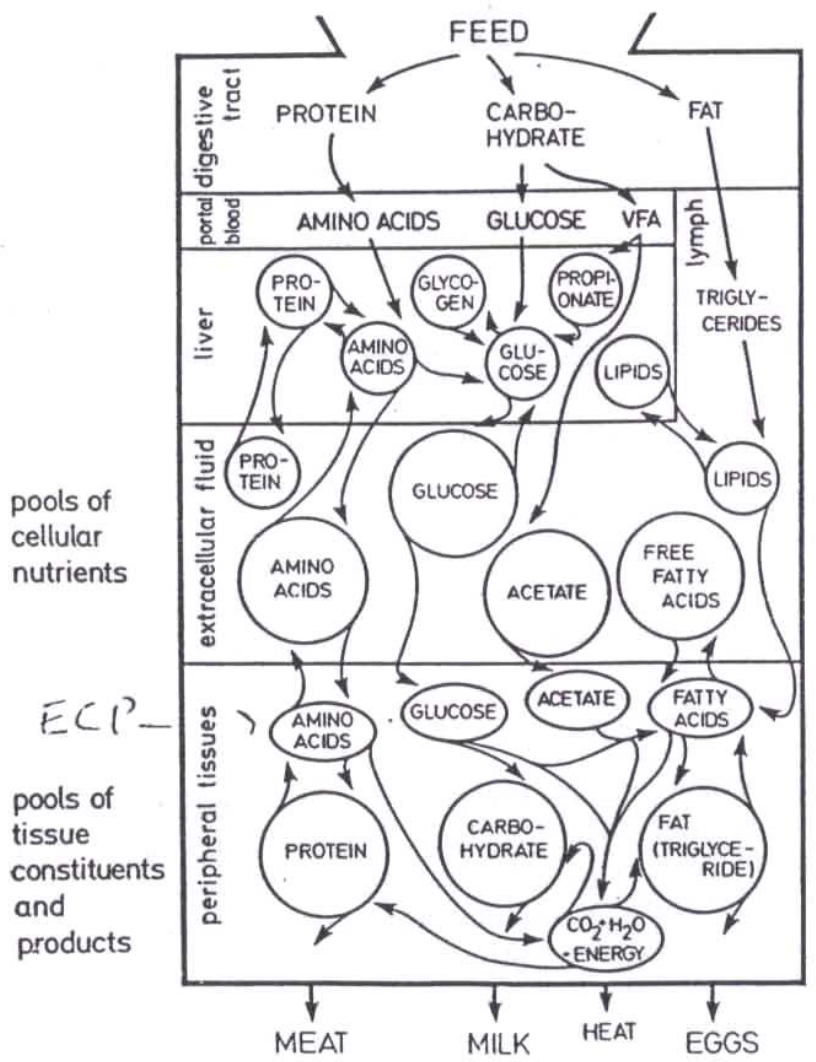

Figure 1. Feed utilization and product formation as a result of pool turn over (Riis and Madsen, 1983)

Stressed animals are more likely to be fractious and likely to fall or bruise themselves, as well as being a danger to the transportation stressor and the correlation on meat quality. 


\section{TRANSPORT STRESS}

Stress can be defined as a physiological and biochemical response as well as behavior changes for any factors such as physical, chemical and biological sources. In the stress condition, animals will attempt to maintain their bodies by perceiving on environment and behaving unusually (Siegel \& Gross, 2000). By ante-mortem stressor includes dehydration, unbalanced electrolyte, negatively balancedenergy, depleted muscle glycogen, and fat and protein catabolism (Schaefer et al., 2001). Furthermore, physiological stressor such as fasting, fatigue, fearness and animals' space density is affected by the distance and length of transport, animal behavior, and type of transportation equipment, the time of transport, climate as well as transportation management (Lawrie, 1991).

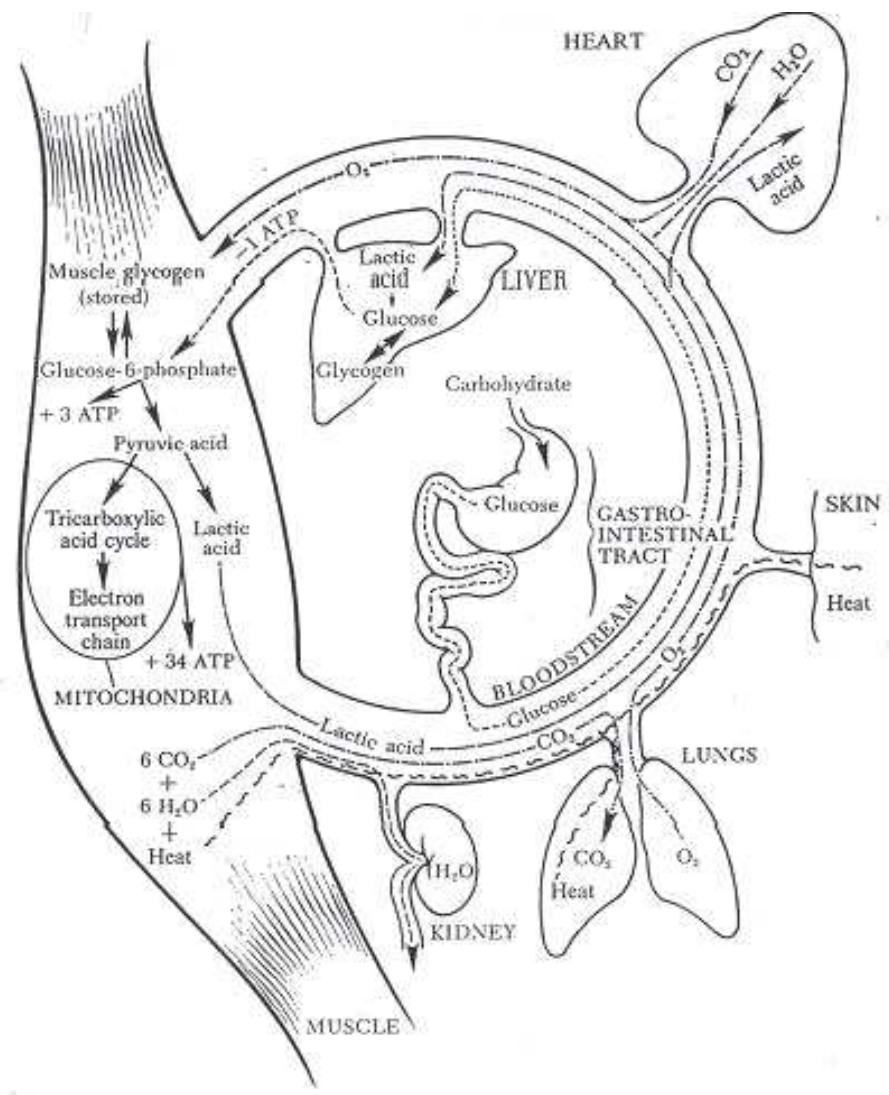

Figure 2. Natural cycle of energy supply for muscle contraction and production (Aberle et al., 2001)

transporting and pre-slaughter handling, cattle can become stress both physically and physiologically (Swanson and MorrowTesch, 2001). Physiological response on
When being stressed, animals attempt to maintain their physiological state by contracting the muscle. Consequently, blood flows to muscle to mobilize glucose 
fast. If the circulation system can't support muscle oxygen and glucose demand, energy for muscle contraction is derived from muscle glycogen breakdown. Due to lack of oxygen, this reaction is out from TCA cycle, but it is in anaerobe pathway. Then, this reaction produces lactic acid larger than of TCA path (Aberle et al., 2001).

Some physiological variables measured in the blood change during transport (Knowles and Warris, 2000). Variables such as free fatty acid, $\beta$ hydroxybutirate, urea, osmolality, total protein, albumin, Pocket Cell Volume (PCV), creatinekinase, vasopressin, cortisol heart beat, and respiration rate increase, whereas blood glucose decrease. Lawrie (1991) states incomplete bleeding when animal is slaughtered.

Experiment on pig indicated that animals transported as long as 8 hours had lower potential glycolisis but higher ultimate $\mathrm{pH}$, shear force value, cooking loss, and drip loss, and its meat was darker than those transported half hour. However, potential glycolisis and other variables were higher than those transported 2.5 hours. These animals, meanwhile, had potential glycolisis and other variables higher than half hour (Laheska et al., 2003). Furthermore, Wulf et al. (2002) states that there was a correlation between potential glycolisis and DFD meat properties which lower potential glycolisis produced DFD meat.

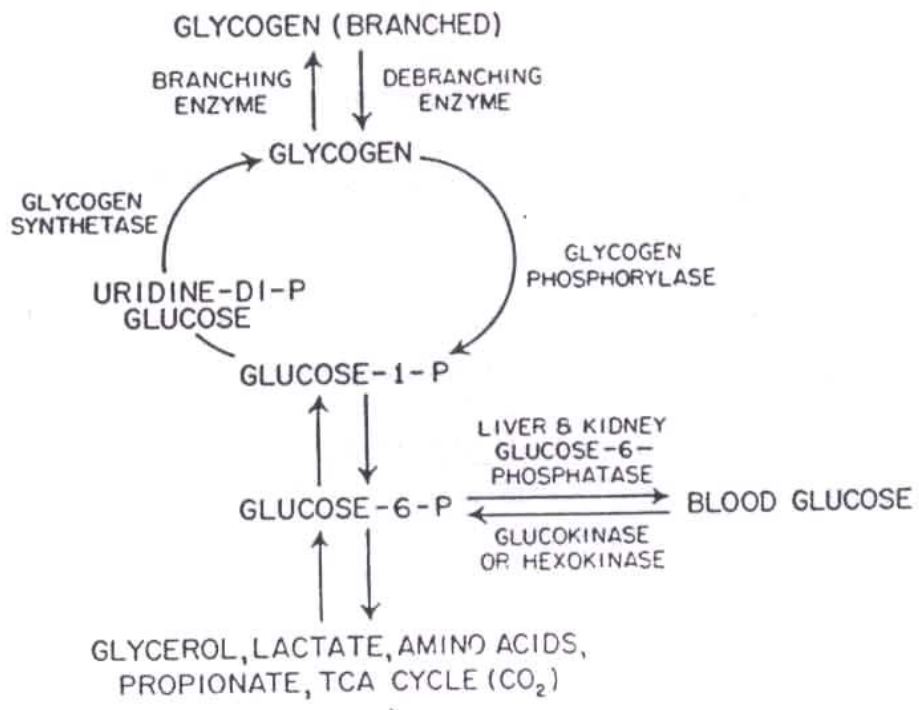

Figure 3. Main path of glycogenesis and glycogenolisis (Bergman, 1983)

transport stress causes reducing muscle glycogen, decreasing body weight and carcass percentage, lack of oxygen and
During transported, animals are fasted. Consequently, the body weight decreases because of the empty of digestive tracts. Knowles and Warris (2000) states that 
ruminants transported as long as $18-34$ hours got lost body weight $7 \%$, and pigs were $4 \%$. Also, 14 hours of transport decreased lambs body weight $6.7 \%$ (Knowles et al., 1993), and animals transported as long as 15 hours got lost 8\% of body weight (Knowles et al., 1995), and for Bali cattle, 48 hours transport loss their body weight 9.77\% (Mas'ud, 1999).

\section{GLYCOGEN AND GLUCOSE METABOLISM}

In normal state, animal body utilizes and metabolizes feed and produce food as shown the figure 1 . The natural cycle of energy supply for muscle energy is shown the figure 2 .

Glycogen is carbohydrate stored in muscle tissue of animal. The most of glycogen are available at muscle and liver. Normal concentration of mammal glycogen is about $0.5-1 \%$ of dry weight and of mammal liver is $2-8 \%$. In spite of little percentage, glycogen is important since it is stored in the muscles composing the body about 80\% (Bergman, 1983).

In the digestive tract, carbohydrate, as monosaccharide type, is absorbed by intestine and transported into heart following blood stream, and then it is synthesized to be glycogen. If needed, glycogen can be broken down into glucose as energy source. The glucose is streamed through blood circulation to muscle tissue, and if the energy is excessive, it will be stored as muscle glycogen (Aberle et al., 2001). Bregman (1983) shows that the glycogenesis takes place in four steps (describe at figure 3), a) Conversing glucose-6-phosphat to glucose-1-phosphat,

b) Formation of UDP-glucose,

c) Formation of linearly glycogen chain via glycogen-synthetase enzyme activity, and

d) Formation of glycogen branches via branching enzyme activity.

Formed glycogen is deposited in the liver and muscle tissues as energy in reserve, and it will be used by breaking down of glycogen called glycogenolisis. This process is catalyzed by glycogen phosphorylase for linear glycogen and branching enzyme for branching glycogen (Bergman, 1983). Besides, blood and heart glucose may be derived from glucogenic compound such as lactic acid generated by anaerobic glycolisis. Then, lactic acid is streamed into heart and hence glucose is formed (Aberle et al., 2001).

Glycogen and glucose metabolism in stressed animal is more fastened by epinephrine and norepinephrine. Based on the functions, these hormones play role in increasing metabolism rate so they support glycogen breakdown in the liver and muscle, and fat stored in the body causing the body mobilizes "ready" energy sources (Aberle et al., 2001). When epinephrine is produced before slaughtering, process of muscle tissue glycolisis takes place maximally. Consequently, the processes of post-mortem glycolisis become faster so it produces PSE meat (Riis, 1983). The PSE is indicated by low $\mathrm{pH}$ ultimate (5.2-5.4) after 6-8 hours slaughtering (Aberle et al., 2001).

PSE takes place because stressed animals overcome increasing glycogen breakdown whereas oxygen supply decreases. In the lack of oxygen, glycolisis happens out of TCA path which it is in anaerobic condition so $\mathrm{H}^{+}$ion released does not be supplied $\mathrm{O}_{2}$ adequately. Because of 
ISSN $1978-3000$

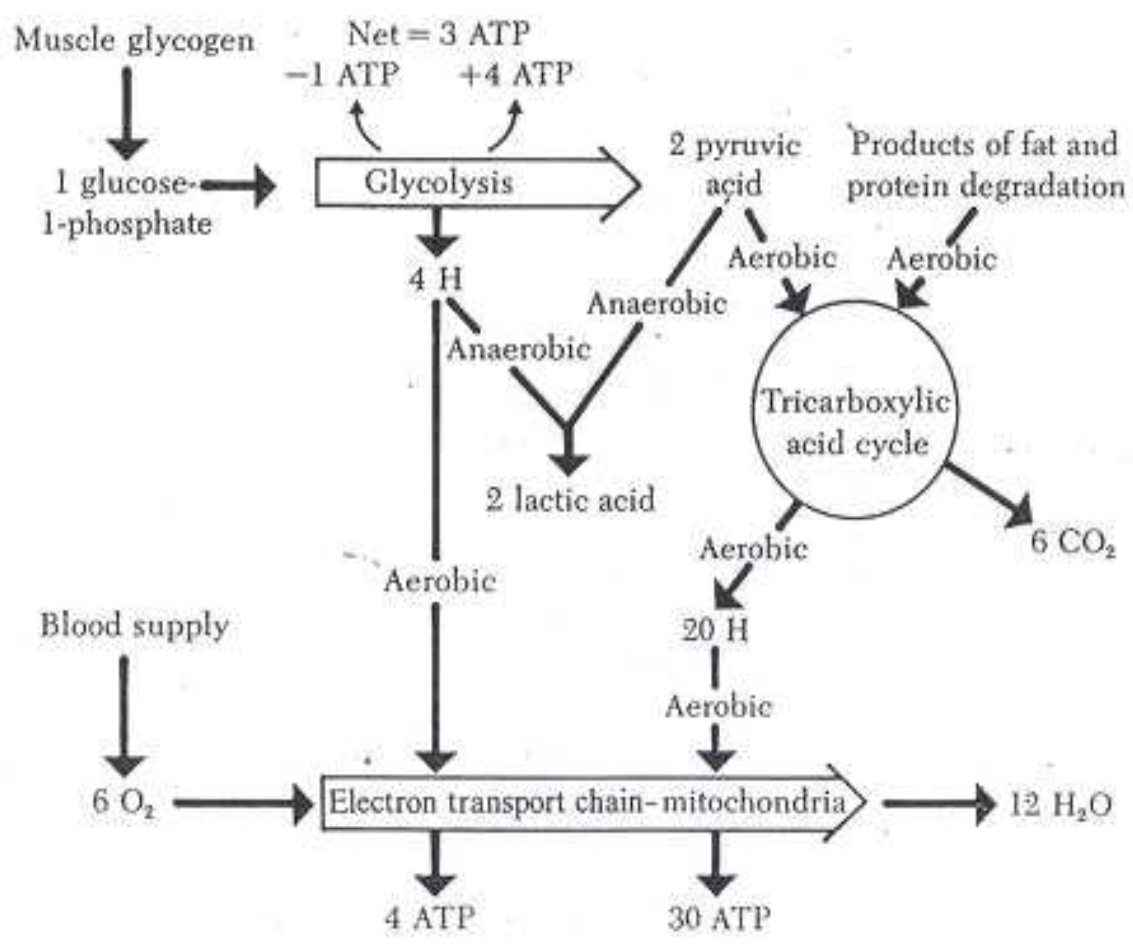

Figure 4. Diagrammatic illustration of energy supply path for muscle contraction (Aberle et al., 2001)

accumulated in the muscle, $\mathrm{H}^{+}$ion is used for conversing pyruvic acid to lactic acid (Lawrie, 1991 and Aberle et al., 2001). Stanley (1988) states that someone who does moderate sport indicates $20 \%$ of glucose usages for lactic acid formation and 20\% blood lactic is from blood glucose which is in the equilibrium condition, glucose is muscle glycogen breakdown. Then, approximately $1 / 5$ carbohydrate oxidized as long as sport enters lactic pool circulation. If anaerobic condition continues, lactic acid production will increase rapidly and decreases meat $\mathrm{pH}$ drastically.

Stressed animals will maintain their homeostatic state by breaking down glycogen via TCA path. If glycogen deficiency comes before animals recover from fatigue, therefore, lactic acid production in the muscle of slaughtered animal is low, and it yields DFD meat (Aberle et al., and Wulf et al., 2002). This meat is indicated by $\mathrm{pH} 6.6-6.8$ after $6-8$ hours slaughtering, dark in color, firm and dry texture (Aberle et al., 2001)

Both DFD and PSE meat are rooted by stress experienced by the live animal at and before slaughter. Acute stress around the time of slaughter leads to PSE meat by stimulating the rate of acidification of the muscles immediately post-mortem so that low $\mathrm{pH}$ values are reached in the muscle when the temperature of the carcass is still high. The ultimate $\mathrm{pH}$ reached in DFD meat can vary considerably, the important point being that it is higher than normal (Warris, 2000).

\section{PRE-SLAUGHTER HANDLING}

Loading and unloading animals can be difficult and stressful. Some vehicles require the use of steep ramps which animals find difficult to negotiate (Warriss, 2000). Based on the metabolic responses for 
transport stress, animal awaiting slaughter has to be held in special pens or areas for calming down (Lawrie, 1991). Metabolic responses for resting animals show glycogen recovery in the body, and the length of upturn depends on the stresses level, treatments and species. Big ruminants will take 6-24 hours, whereas the small one takes $2-4$ hours.

During resting, animals are treated by electrolyte or sugar solution or drinking water supplementation. Electrolyte solution is effective for maintaining extra cellular matrix and reducing negative effects of transport (Gortel et al., 1992). According to Schaefer et al. (1990), glucose and electrolyte solution supplementation before slaughter may reduce stress effect during transport and enhance the meat quality. While, sugar and insulin supplementation and the length of resting can lessen negative stress of transport on sheep and prevent DFD meat case (Dewi, 2004).

\section{CONCLUSION}

Transportation is a chain of animals and the product distribution from farm to consumers. However, transport is a premortem factor affecting meat quality. During transporting, animals suffer stress and it will influence metabolic mechanism of animal body. Stressed animal will drive glycogen and glucose metabolism considerably. Glycogen breakdown increase drastically because energy requirement to serve body homeostatic increases, too.

Glycogenolysis and glycolysis process can be in aerobic (TCA cycle) and anaerobic condition. If anaerobic condition is dominant, it will produce lactic acid increasingly and cause PSE meat. If the animals are able to maintain the physiological equilibrium by using muscle glycogen up, it causes glycogen deficiency and yields DFD meat.

For avoiding both cases, preslaughter handling is an important stage. The ways of it are adequate resting time, giving electrolyte and sugar solution and so on.

\section{REFERENCES}

Aberle, E.D., J.C. Forrest, D.E. Gerrard and E.W. Mills. 2001. Principles of Meat Science, $4^{\text {th }}$ edition. Kendall/Hunt Publishing, Iowa.

Bergman, E.M. 1983. The pools of tissue constituents and products: carbohydrates. In: Dynamic Biochemistry of Animal Production, P.M. Riis (ed). Elsevier, Amsterdam, Oxford, New York, Tokyo.

Dewi, S.C.H. 2004. Pengaruh Pemberian Gula, Insulin dan Lama Istirahat sebelum Pemotongan pada Domba setelah Pengangkutan terhadap Kualitas Daging. Disertasi, Sekolah Pascasarjana, IPB,Bogor.

Gortel, K., A.L. Schaefer, B.A. Young and S.C. Kawamoto, 1992. Effect of transport stress and electrolyte supplementation on body fluids and weight of bulls. J. Anim. Sci. 72: 547553.

Grandin, T. 2000. Introduction: Management and Economic Factors of Handling and Transport. In: Livestock Handling and Transport $2^{\text {nd }}$ edition, T. Grandin (ed). CABI Publishing, London.

Knowles, T.G. and P.D. Warriss. 2000. Stress Physiology of Animals during Transport. In: In: Livestock Handling 
and Transport $2^{\text {nd }}$ edition, T. Grandin (ed). CABI Publishing, London.

Knowles, T.G., P.D. Warriss, S.N. Brown, S.C. Kestin, S.M. Rhind, J.E. Edwards, M.H. Anil and S.K. Dolan. 1995. Long distance transport of lambs and the time neede for subsequent recovery. Veterinary Record 133: 286-293.

Lawrie, R.S. 1991. Meat Science, $5^{\text {th }}$ edition. Pergamon Press, Oford, New York, Seoul, Tokyo.

Leheska, J.M. D.M. Wulf, and R.J. Maddock. 2003. Effects of fasting and transportation on pork quality development and extent of postmortem metabolism. J. Anim. Sci. 81:3194-3202.

Mas'ud, M.S. 1999. Pengaruh lama istirahat terhadap kadar asam laktat, glukosa dan magnesium darah sapi Bali. Tesis, Program Pascasarjana, IPB, Bogor.

Riis, P.M. 1983. Adaptation of metabolism to various condition: Nutritional and their environmental conditions, In: Dynamic Biochemistry of Animal Production, P.M. Riis (ed). Elsevier, Amsterdam, Oxford, New York, Tokyo.

Riis, P.M and A. Maden, 1983. Introduction to volum, In: Dynamic Biochemistry of Animal Production, P.M. Riis (ed). Elsevier, Amsterdam, Oxford, New York, Tokyo.
Schaefer, A.L., P.L. Dubeski, J.L. Aalhus and A.K.W. Tong. 2001. Role of Nutrition in reducing antemortem stress and meat quality aberrations. J., Anim.Sci. 79(E.Suppl):E91-E101.

Schaefer, A.L., S.D.M. Jones, A.K.W. Tong, B.A. Young. 1990. Effect of transport and electrolyte supplementation on ion concentration, carcass yield and quality in bulls. J. Anim. Sci. 70:107119.

Siegel, P.B. and W.B. Gross. 2000. General principles of stress and well-being. In: Livestock handling and Transport $2^{\text {nd }}$ edition, $\mathrm{T}$ Granding (Ed). Cabi Publishing, London.

Stanley, W.C., J.A. Wisneski, E.W. Gerzt, R.A. Neese and G.A. Brooks. 1988. Glucose and lactate interrelations during moderate-intensity exercise in human metabolism 37: 850-858.

Swanson, J.C. and J. Morrow-Tesch. 2001. Cattle transport: historical, research, and future perspectives. J. Anim. Sci. 79 (Esuppl): E102-E109.

Warris, P.D. 2004. Meat Science; an introductory text. Cabi Publishing, London.

Wulf, D.M., R.S. Leheska, and S.J. Moeller. 2002. Relationships among glycolitic potential, dark cutting (dark, firm, and dry) beef, and cooked beef palatability. J. Anim. Sci. 80:18951903. 